\title{
PENGARUH KEBUTUHAN PRESTASI, KEBUTUHAN AFILIASI DAN KEBUTUHAN KEKUASAAN TERHADAP SEMANGAT KERJA DOSEN PADA SEKOLAH TINGGI ILMU EKONOMI AMA SALATIGA
}

Oleh :

Edi Murgijanto

Dosen Tetap STIE AMA Salatiga

\begin{abstract}
Abstrak
Sekolah Tinggi Ilmu Ekonomi AMA Salatiga dalam mencapai tujuan harus melibatkan para dosen melalui aktivitas-aktivitas yang bidang pendidikan dan pengajaran, penelitian serta pengabdian kepada masyarakat (Tridharma Perguruan Tinggi). Oleh karena itu diperlukan pengelolaan yang tepat terkait kebutuhan para dosen, baik kebutuhan prestasi, kebutuhan afiliasi maupun kebutuhan kekuasaan agar para dosen dapat bekerja dengan semangat kerja yang lebih tinggi.

Penelitian ini dilakukan untuk mengetahui pengaruh kebutuhan prestasi, kebutuhan afiliasi dan kebutuhan kekuasaan terhadap semangat kerja dosen pada Sekolah Tinggi Ilmu Ekonomi AMA Salatiga. Berdasarkan hasil analisis data, peneliti dapat menarik kesimpulan tentang pengaruh kebutuhan prestasi, kebutuhan afiliasi dan kebutuhan kekuasaan terhadap semangat kerja dosen STIE AMA Salatiga sebagai berikut: 1) Variabel kebutuhan prestasi mempunyai nilai thitung $0,830<t_{\text {tabel }} 2,08$, dan variabel kebutuhan kekuasaan mempunyai nilai thitung $1,094<t_{\text {tabel }} 2,08$, hal ini berarti kedua variabel tersebut menunjukkan tidak terdapat pengaruh yang signifikan antara masing-masing kedua variabel terhadap semangat kerja. 2) Variabel kebutuhan afiliasi mempunyai nilai thitung3,212> ttabel 2,08, hal ini berarti variabel kebutuhan afiliasi menunjukkan terdapat pengaruh yang signifikan terhadap semangat kerja. 3) Sedangkan variabel kebutuhan prestasi, kebutuhan afiliasi dan kebutuhan kekuasaan secara simultan mempunyai nilai $F_{\text {hitung }} 4,770>F_{\text {tabel }} 3,07$, hal ini berarti variabel kebutuhan prestasi, kebutuhan afiliasi dan kebutuhan kekuasaan secara simultan terdapat pengaruh yang signifikan terhadap semangat kerja. 4) Besarnya nilai koefisien determinasi (Adjusted $R$ Square $)=0,32$ hal ini berarti variabel independen kebutuhan prestasi (X1), kebutuhan afiliasi (X2) dan kebutuhan kekuasaan (X3) dapat menjelaskan variabel dependen semangat kerja $(Y)$ sebesar $32 \%$ sedang sisanya $68 \%$ dijelaskan oleh sebab faktor lain yang tidak diteliti.

Saran dalam penelitian ini adalah ada baiknya apabila pihak STIE AMA Salatiga dan Yayasan berusaha meningkatkan kebutuhan afiliasi secara khusus tanpa melupakankebutuhan prestasi dan kebutuhan kekuasaan guna meningkatkan semangat kerja dosen STIE AMA Salatiga.
\end{abstract}

Kata kunci: Kebutuhan Prestasi, Kebutuhan Afiliasi, Kebutuhan Kekuasaan, Semangat Kerja.

Pengaruh Kebutuhan Prestasi, Kebutuhan Afiliasi 


\section{PENDAHULUAN}

Sumber daya manusia merupakan faktor penting dalam suatu organisasi termasuk lembaga pendidikan tinggi.Hal ini disebabkan karena sumber daya manusia merupakan modal dasar organisasi untuk melakukan aktivitas dalam mencapai tujuan.Lembaga pendidikan tinggi dalam hal ini perguruan tinggi didirikan mempunyai fungsi dan peran antara lain sebagai pusat pengembangan Ilmu Pengetahuan dan Teknologi, pusat kajian kebajikan dan kekuatan moral untuk mencari dan menemukan kebenaran, dan pusat pengembangan peradaban bangsa.

Fungsi dan peran tersebut dilaksanakan oleh para dosen.Oleh karena itu dosen mempunyai fungsi dan peran yang sangat penting pada perguruan tinggi.Hal ini dapat dilihat dari segala aktivitas yang dilaksanakan para dosen melalui kegiatan-kegiatandi bidang pendidikan, penelitian serta pengabdian kepada masyarakat yang dikenal dengan Tridharma Perguruan Tinggi.

Untuk menunjang fungsi dan peran dosen pada perguruan tinggi diperlukan adanya sumber daya manusia dosen yang berkualitas, mempunyai loyalitas dan dedikasi yang tinggi terhadap pekerjannya serta adanya semangatdalam bekerja.Agar para dosen

bersemangat dalam bekerja maka harus ada pendorong semangat kerja.Pendorong semangat kerja ini diantaranya adalahkebutuhan prestasi, kebutuhan afiliasi dan kebutuhan kekuasaan.

Menurut Mc. Clelland dalam Moh.As'ad (2002) timbulnya tingkah laku karena dipengaruhi oleh kebutuhan-kebutuhan yang ada dalam diri manusia. Selanjutnya dijelaskan dalam konsepnya mengenai motivasi, dalam diri individu terdapat tiga kebutuhan pokok yang mendorong tingkah lakunya yaitu need for achievement (n.Ach), need for affiliation (n.Aff) dan need for power (n.Pow).

Pendapat David Mc. Clelland dalam Sukanto Reksohadiprodjo dan T. Hani Handoko (2000), seseorang dianggap mempunyai motivasi yang tinggi apabila dia mempunyai keinginan untuk berprestasi lebih baik daripada yang lain dalam banyak situasi. Karena ke tiga kebutuhan manusia yaitu need for achievement (kebutuhan prestasi), need for affiliation (kebutuhan afiliasi)dan need for power (kebutuhan 
kekuasaan)telah terbukti merupakan unsur-unsur penting yang ikut menentukan prestasi pribadi dalam berbagai situasi kerja dan cara hidup.

Dalam memotivasi para bawahan, Malayu S.P. Hasibuan (2003) menjelaskan bahwa pemimpin hendaknya menyediakan peralatan, menciptakan suasana pekerjaan yang baik dan memberi kesempatan promosi, sehingga memungkinkan para bawahan akan meningkat semangat kerjanya untuk mencapai n.Ach, n.Aff dan n.Pow. Karena n.Ach, n.Aff dan n.Pow ini merupakan daya penggerak yang dapat memotivasi karyawan untuk mengerahkan semua potensi yang dimilikinya.

Keberhasilan dosen sebagai tenaga edukatif dalam menjalankan fungsi dan perannya pada perguruan tinggi dipengaruhi banyak faktor, salah satunya adalah faktor semangat kerja.Tinggi rendahnya semangat kerja, selanjutnya sangat berpengaruh terhadap kinerja yang dapat dicapai oleh dosen yang dimanifestasikan dalam bentuk kreativitas dan inisiatif dalam bidang pendidikan, penelitian serta pengabdian kepada masyarakat yang dikenal dengan Tridharma Perguruan Tinggi. Apabila terdapat semangat kerja pada diri dosen, dapat diharapkan tugas yang diberikan akan dilakukan lebih cepat dan baik.

Menurut Menurut Alex S. Nitisemito (2001), semangat kerja adalah melakukan pekerjaan dengan lebih giat, sehingga pekerjaan akan dapat diselesaikan dengan lebih cepat dan lebih baik.

Sekolah Tinggi Ilmu Ekonomi AMA Salatiga merupakan organisasi yang bergerak dibidang pendidikan tinggi. Dalam organisasi seperti ini, dosen merupakan salah satu unsur yang melakukan proses untuk menciptakan keluaran yang baik. Sumber keefektifan dosen dalam berkinerja mencakup antara lain kompensasi, kepuasan kerja, motivasi, kemampuan, pengetahuan, keahlian, sikap dan stres. Perbedaan yang dipengaruhi oleh motivasi dapat menyebabkan perbedaan semangat kerja masing-masing dosen.

Bertitik tolak dari pengetahuan tentang peran dan dampak kebutuhan prestasi, kebutuhan afiliasi dan kebutuhan kekuasaanterhadap semangat kerja dosen sebagaimana diuraikan diatas, maka penulis akan mengadakan penelitian mengenai "Pengaruh 
Kebutuhan Prestasi, Kebutuhan Afiliasi dan Kebutuhan KekuasaanTerhadap Semangat Kerja Dosen pada Sekolah Tinggi Ilmu Ekonomi AMA Salatiga”.

\section{Rumusan Masalah}

Berdasarkan uraian latar belakang diatas maka rumusan permasalahan penelitian ini adalah :

Adakah pengaruh Kebutuhan Prestasi, Kebutuhan Afiliasi dan Kebutuhan KekuasaanTerhadap Semangat Kerja Dosen pada Sekolah Tinggi Ilmu Ekonomi AMA Salatiga?

\section{Tujuan Penelitian}

Tujuan Penelitian iniadalah untuk mengetahui pengaruh Kebutuhan Prestasi, Kebutuhan Afiliasi dan Kebutuhan Kekuasaanbaik secara sendiri-sendiri maupun secara simultan terhadap Semangat Kerja dosen pada Sekolah Tinggi Ilmu Ekonomi AMA Salatiga.

\section{LANDASAN TEORI}

\section{Achievement Motivation Theory (AMT)}

Teori ini berpendapat bahwa karyawan mempunyai cadangan energi potensial.Bagaimana energi dilepaskan dan dimanfaatkan tergantung pada kekuatan/ dorongan/ motivasi seseorang dan situasi serta peluang yang tersedia.

Teori motivasi David Mc. Clelland disebut Achievement Motivation Theory (AMT) atau Teori Motivasi Berprestasiyang berfokus pada ketiga jenis kebutuhan yaitu:

a. Kebutuhan akan prestasi (need for achievement $=n$ Ach).

b. Kebutuhan akan afiliasi(need for affiliation $=n$ Aff $)$.

c. Kebutuhan akan kekuasaan (need for power $=n$ Pow).

(Mc. Clelland dalam Hasibuan, 2003).

\section{Kebutuhan akanPrestasi (Need for Achievement $=n$ Ach $)$.}

Menurut Moh. As'ad (2002), kebutuhan akan prestasi (need for achievement) merupakan kebutuhan untuk mencapai sukses, yang diukur berdasarkan standar kesempurnaan dalam diri seseorang. Kebutuhan ini berhubungan erat dengan pekerjaan, dan mengarahkan tingkah laku pada usaha untuk mencapai prestasi tertentu. 
Menurut Moh. As'ad (2002), ciri-ciri kebutuhan berprestasi yang tinggi akan tampak sebagai berikut:

a. Berusaha melakukan sesuatu dengan cara-cara baru dan kreatif.

b. Mencari feed back (umpan balik) tentang perbuatannya.

c. Memilih resiko yang moderat (sedang) di dalam perbuatannya.

d. Mengambil tanggung jawab pribadi atas perbuatan-perbuatannya.

Menurut Ashar Sunyoto Munandar (2004), kebutuhan untuk berprestasi (need for achievement $=n A c h)$ adalah dorongan yang kuat untuk berhasil, lebih mengejar prestasi pribadi dan bergairah melakukan sesuatu lebih baik dan lebih efisien dibandingkan hasil sebelumnya.

Menurut Ashar Sunyoto Munandar (2004), orang yang memiliki kebutuhan berprestasi yang tinggi adalah sebagai berikut:

a. Menyukai pekerjaan dengan tanggung jawab pribadi.

b. Mendapatkan umpan balik atas pekerjaannya.

c. Memilih pekerjaan yang memiliki resiko sedang/moderat.

Kebutuhan akan Afiliasi(Need for Affiliation = $\boldsymbol{n}$ Aff $)$.

Menurut Moh. As'ad (2002), kebutuhan akan afiliasi(need for affiliation $=n$ Aff) merupakan kebutuhan akan kehangatan dan bantuan dalam hubungannya dengan orang lain. Kebutuhan ini mengarahkan tingkah laku untuk mengadakan hubungan secara akrab dengan orang lain.

Menurut Moh. As'ad (2002), ciri-ciri kebutuhan afiliasi/persahabatan yang tinggi akannampak sebagai berikut:

a. Lebih memperhatikan segi hubungan pribadi yang ada dalam pekerjaannya, daripada segi tugas-tugas yang ada pada pekerjaan itu sendiri.

b. Melakukan pekerjaannya lebih efektif apabila bekerjasama bersama orang lain dalam suasana yang lebih kooperatif.

c. Mencari persetujuan atau kesepakatan dari orang lain.

d. Lebih suka dengan orang lain daripada sendirian. 
Menurut Ashar Sunyoto Munandar (2004), kebutuhan untuk berafiliasi(need for affiliation $=n$ Aff) adalah kebutuhan untuk mendapatkan persahabatan, diterima dalam kelompok, menyukai situasi kooperatif dan menghindari konflik.

Menurut Ashar Sunyoto Munandar (2004), orang dengan kebutuhan untuk berafiliasi yang tinggi adalah:

a. Mempunyai kebutuhan untuk mendapatkan persahabatan.

b. Keinginan diterima dalam kelompok.

c. Menyukai situasi kooperatif.

d. Menghindari konflik.

Kebutuhan akan Kekuasaan $($ Need for Power $=n$ Pow $)$.

Menurut Moh. As'ad (2002), kebutuhan akan kekuasaan (need for power $=n$ Pow) merupakan kebutuhan untuk menguasai dan mempengaruhi terhadap orang lain. Kebutuhan ini menyebabkan orang yang bersangkutan tidak atau kurang memperdulikan perasaan orang lain.

Menurut Moh. As'ad (2002), ciri-ciri kebutuhan berkuasa yang tinggi akan nampak sebagai berikut:

a. Berusaha menolong orang lain walaupun pertolongan itu tidak diminta.

b. Sangat aktif dalam menentukan arah kegiatan dari organisasi di mana ia berada.

c. Mengumpulkan barang-barang atau menjadi anggota suatu perkumpulan yang dapat mencerminkan prestise.

d. Sangat peka terhadap struktur pengaruh antar pribadi dari kelompok atau organisasi.

Menurut Ashar Sunyoto Munandar (2004), kebutuhan untuk berkuasaan (need for power $=n$ Pow ) adalah keinginan yang kuat untuk mengendalikan orang lain, untuk mempengaruhi orang lain, dan untuk memiliki dampak terhadap orang lain.

Menurut Ashar Sunyoto Munandar (2004), orang dengan kebutuhan berkuasa yang besar adalah:

a. Keinginan yang kuat untuk mengendalikan orang lain.

b. Keinginan untuk mempengaruhi orang lain.

c. Keinginan untuk memiliki dampak terhadap orang lain. 


\section{Semangat Kerja}

Menurut Alex S. Nitisemito (2001), semangat kerja adalah melakukan pekerjaan dengan lebih giat, sehingga pekerjaan akan dapat diselesaikan dengan lebih cepat dan lebih baik.

Menurut Alex S. Nitisemito (2001), cara-cara untuk meningkatkan semangat kerja yaitu:

a. Gaji yang cukup.

b. Memperhatikan kebutuhan rohani.

c. Menciptakan suasana santai.

d. Harga diri diperhatikan.

e. Menempatkan karyawan pada posisi yang tepat.

f. Memberikan kesempatan untuk maju.

g. Perasaan aman dalam menghadapi masa depan.

h. Usahakan karyawan mempunyai loyalitas.

i. Sekali-kali karyawan diajak berunding.

j. Memberikan insentif terarah

k. Fasilitas yang menyenangkan.

Adapun kerangka pemikiran dalam penelitian ini dapat digambarkan dengan model sebagai berikut :

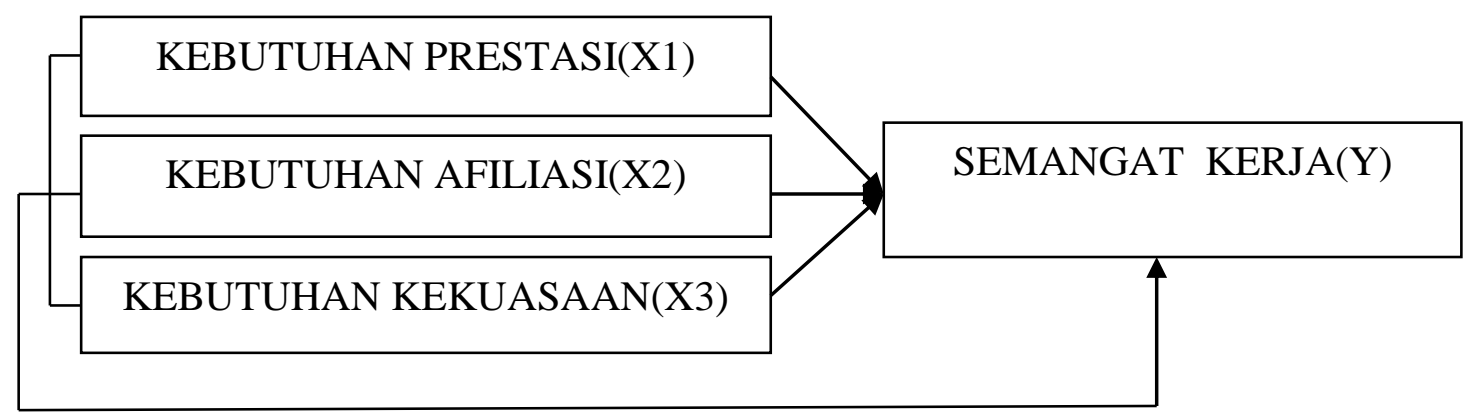

Gambar 1 : Kerangka Teoritis 


\section{Hipotesis}

Berdasarkan pada perumusan masalah dan landasan teori di atas maka penulis membuat hipotesis sebagai berikut: Ada pengaruh yang signifikan kebutuhan prestasi, kebutuhan afiliasi dan kebutuhan kekuasaanbaik secara parsial maupun secara simultan terhadap semangat kerja dosen pada Sekolah Tinggi Ilmu Ekonomi AMA Salatiga.

\section{METODE PENELITIAN}

\section{Tipe Penelitian}

Dalam penelitian ini tipe penelitiannya termasuk tipe penelitian Eksplanatori. Penelitian eksplanatori adalah penelitian yang berusaha untuk menguji hipotesis yang menyatakan hubungan sebab akibat antara dua variabel atau lebih (Sukandarrumidi, 2006).

\section{Populasi dan Sampel}

Dalam penelitian ini yang menjadi populasi adalah dosen Sekolah Tinggi Ilmu Ekonomi AMA Salatiga yang berjumlah 30 orang dosen. Menurut Suharsimi Arikunto (2002) apabila subyeknya kurang dari 100 lebih baik diambil semua sehingga penelitiannya merupakan penelitian populasi.

\section{Definisi Operasional}

Definisi operasional dalam penelitian ini adalah sebagai berikut:

Kebutuhan Prestasi (X1) diukur dengan indikator-indikator yaitu:menyukai pekerjaan dengan tanggung jawab pribadi,mendapatkan umpan balik atas pekerjaannya,menyukai pekerjaan yang memiliki tingkat resiko sedang/moderat.

Kebutuhan Afiliasi(X2) diukur dengan indikator-indikator yaitu:mempunyai kebutuhan untuk mendapatkan persahabatan, keinginan diterima dalam kelompok, menyukai situasi kooperatif, menghindari konflik.

Kebutuhan Kekuasaan (X3) diukur dengan indikator-indikator yaitu:keinginan yang kuat untuk mengendalikan orang lain, keinginan untuk mempengaruhi orang lain, keinginan untuk memiliki dampak terhadap orang lain. 
Semangat Kerja(Y) diukur dengan indikator-indikator yaitu:kompensasi non finansial, mengampu mata kuliah sesuai dengan kompetensi, adanya peningkatan kompetensi, perasaan ikut memiliki.

Dalam penelitian ini, skala Likert digunakan untuk mengukur sikap, pendapat dan persepsi responden atas pertanyaan yang diajukan sebagai berikut :

Sangat Setuju (SS) diberi skor 5, Setuju (S) diberi skor 4, Ragu-Ragu (RR) diberi skor 3, Tidak Setuju (TS) diberi skor 2, Sangat Tidak Setuju (STS) diberi skor 1.

\section{Jenis data}

Jenis data yang digunakan dalam penelitian ini adalah:Data Primer, yaitu data yang diperoleh langsung dari para dosen Sekolah Tinggi Ilmu Ekonomi AMA Salatiga, dengan menggunakan kuesioner dan pengamatan serta Data Sekunder, yaitu data yang diperoleh secara tak langsung dari Sekolah Tinggi Ilmu Ekonomi AMA Salatiga dengan mempelajari buku-buku dan dokumen-dokumen berkaitan dengan penelitian.

\section{Metode Pengumpulan data}

Metode pengumpulan data yang digunakan dengan metode Kuesioner yaitu sejumlah pertanyaan secara tertulis yang digunakan untuk memperoleh informasi dari para dosen STIE AMA Salatiga. Kemudian Observasi dengan mengamati secara langsung lokasi obyek penelitian(STIE AMA Salatiga). Serta Metode Dokumentasidengan mempelajari dokumen-dokumen, buku-buku yang terkait dengan penelitian.

\section{Metode Analisis Data}

Analisis data penelitian ini menggunakan beberapa teknik analisis sebagai berikut :

\section{Uji Validitas}

Uji validitas adalah untuk mengukur tingkat kesahihan instrumen tentang apa yang seharusnya diukur.Untuk mengukur validitas digunakan rumus korelasi product moment Pearson, bila :

$\mathrm{r}$ hitung $>\mathrm{r}$ tabel, berarti pengujian validitas dikatakan valid.

$\mathrm{r}$ hitung $\leq \mathrm{r}$ tabel, berarti pengujian validitas dikatakan tidak valid. 


\section{Uji Reliabilitas}

Pengukuran yang memiliki reliabilitas tinggi disebut sebagai pengukuran yang reliabel.Suatu alat ukur dikatakan reliabel jika koefisien Alpha/Cronbach Alpha > 0,60 (Nunnally, dalam Imam Gozali, 2001).

\section{Analisis Regresi Linear Berganda}

Analisis dilakukan dengan rumus regresi linear berganda sebagai berikut:

$\mathrm{Y}=\mathrm{a}+\mathrm{b} 1 \mathrm{X} 1+\mathrm{b} 2 \mathrm{X} 2+\mathrm{b} 3 \mathrm{X} 3$.

Dimana : Y adalah variabel semangat kerja, a adalahbilangan konstan, b1, b2 dan b3 adalah koefisien regresi, X1 adalah variabel kebutuhan prestasi, X2 kebutuhan afiliasi dan X3 adalah variabel kebutuhan kekuasaan.

\section{Uji t}

Uji t dilakukan untuk mengetahui pengaruhkebutuhan prestasi (X1), kebutuhan afiliasi (X2) dan kebutuhan kekuasaan(X3) secara partial terhadap semangat kerja (Y).

Ho: $\beta 1, \beta 2, \beta 3=0$, berarti tidak ada pengaruh yang signifikan antara $(\mathrm{X} 1),(\mathrm{X} 2)$ dan $(\mathrm{X} 3)$ secara partial, terhadap (Y).

Ha: $\beta 1, \beta 2, \beta 3 \neq 0$, berarti ada pengaruh yang signifikan antara (X1), (X2) dan (X3) secara partial, terhadap (Y).

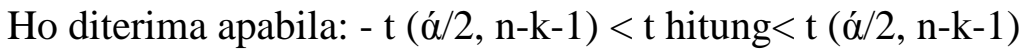

Ha diterima apabila: $\mathrm{t}$ hitung $>\mathrm{t}(\dot{\alpha} / 2, \mathrm{n}-\mathrm{k}-1)$ atau $-\mathrm{t}$ hitung $<-\mathrm{t}(\dot{\alpha} / 2, \mathrm{n}-\mathrm{k}-1)$

\section{Uji F}

Uji F dilakukan untuk mengetahui pengaruh kebutuhan prestasi (X1), kebutuhan afiliasi (X2) dan kebutuhan kekuasaan(X3) secara simultan terhadap semangat kerja (Y).

Ho: $\beta 1, \beta 2, \beta 3=0$, berarti tidak ada pengaruh yang signifikan antara $(\mathrm{X} 1),(\mathrm{X} 2)$ dan $(\mathrm{X} 3)$ secara simultan, terhadap $(\mathrm{Y})$.

Ha: $\beta 1, \beta 2, \beta 3>0$, berarti ada pengaruh yang signifikan antara $(\mathrm{X} 1),(\mathrm{X} 2)$ dan $(\mathrm{X} 3)$ secarasimultan, terhadap (Y).

$\mathrm{H}_{0}$ diterima dan $\mathrm{Ha}$ ditolak bila $\mathrm{F}_{\text {hitung }}<\mathrm{F}_{\text {tabel }}$ $\mathrm{H}_{0}$ ditolak Ha diterima bila nilai $\mathrm{F}_{\text {hitung }}>\mathrm{F}_{\text {tabel. }}$ 


\section{Koefisien Determinasi (Adjusted R Square)}

Koefisien determinasi digunakan untuk mengetahui besarnya sumbangan variabel independenkebutuhan prestasi (X1), kebutuhan afiliasi (X2) dan kebutuhan kekuasaan(X3) terhadap variabel dependen semangat kerja(Y)yang ditunjukkan oleh nilai Adjusted R Square.

\section{HASIL PENELITIAN}

Penelitian ini sebagai responden adalah dosen Sekolah Tinggi Ilmu Ekonomi AMA Salatiga yang berjumlah 30 orang dosen, namun yang menyerahkan kembali kuesioner dan memberi tanggapan sebanyak 25 orang dosen.

Dari hasil analisis data penelitian dapat diuraikan penjelasan sebagai berikut :

\section{Hasil Uji Validitas Kuesioner Penelitian}

Dari hasil analisis uji validitas didapati bahwa nilai rhitung masing-masing butir pertanyaan > rtabel $(0,396)$. Oleh karena itu kuesioner penelitian dikatakan valid.

\section{Hasil Uji Reliabilitas Kuesioner Penelitian}

Berdasarkan hasil uji dengan SPSS diperoleh hasil bahwa nilai cronbach alpha $>0,6$ sehingga indikator pada masing-masing variabel penelitian dapat dikatakan reliabel.

\section{Analisis Regresi Linier Berganda}

Dari hasil analisis regresi linier bergandapengaruh antara kebutuhan prestasi, kebutuhan afiliasi dan kebutuhan kekuasaanyang merupakan variabel independen terhadap semangat kerja yang merupakan variabel dependendiuraikan pada tabel di bawah ini :

\section{Tabel 1}

\section{Hasil Perhitungan Regresi Linier Berganda}

\begin{tabular}{|c|c|c|c|c|c|c|}
\hline \multicolumn{7}{|c|}{ Coefficientsa } \\
\hline \multirow{2}{*}{\multicolumn{2}{|c|}{ Model }} & \multicolumn{2}{|c|}{ Unstandardized Coefficients } & \multirow{2}{*}{$\begin{array}{c}\begin{array}{c}\text { Standardized } \\
\text { Coefficients }\end{array} \\
\text { Beta }\end{array}$} & \multirow[b]{2}{*}{$\mathrm{T}$} & \multirow[b]{2}{*}{ Sig. } \\
\hline & & B & Std. Error & & & \\
\hline \multirow[t]{4}{*}{1} & (Constant) & 5.270 & 5.311 & & .992 & .332 \\
\hline & $\begin{array}{l}\text { KEBUTUHAN PRESTASI } \\
(\mathrm{X} 1)\end{array}$ & .157 & .189 & .147 & .830 & .416 \\
\hline & KEBUTUHAN AFILIASI (X2) & .514 & .160 & .559 & 3.212 & .004 \\
\hline & $\begin{array}{l}\text { KEBUTUHAN KEKUASAAN } \\
(\mathrm{X} 3)\end{array}$ & .137 & .125 & .189 & 1.094 & .286 \\
\hline
\end{tabular}

a. Dependent Variable: SEMANGAT KERJA (Y)

Sumber : Data Primer Yang Diolah, 2017 
Dari model regresi di atas diperoleh persamaan garis regresi $\mathrm{Y}=5,270+0,157 \mathrm{X} 1$ $+0,514 \mathrm{X} 2+0,137 \mathrm{X} 3$.

\section{Uji Hipotesis Penelitian}

\section{Pengujian Hipotesis I Penelitian}

Dari hasil analisis data diperoleh nilai t-hitung sebagai berikut:

Pengujian hipotesis I dilakukan dengan uji t. Pengujian ini bertujuan untuk mengetahui pengaruh kebutuhan prestasiterhadap semangat kerja dosen pada Sekolah Tinggi Ilmu Ekonomi AMA Salatiga.

Dengan menggunakan taraf signifikansi 0,025 ( $\alpha=0,05 / 2)$, dan degree of freedom

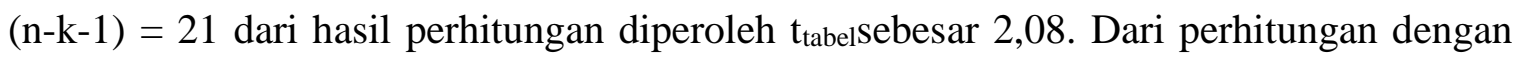
program SPSSdihasilkan $t_{\text {hitungsebesar }}$ 0,830,sehingga $t_{\text {hitung }}$ lebih kecil daripada $t_{\text {tabel }}$ $(0,830<2,08)$ dengan tingkat signifikansi $0,416>0,025$, sehingga keputusannya adalah menerima $\mathrm{H}_{\mathrm{o}}$ dan menolak $\mathrm{H}_{\mathrm{a}}$.

Sehingga pernyataan hipotesis I penelitian “Terdapat pengaruh yang signifikan kebutuhan prestasi terhadap semangat kerja dosen pada Sekolah Tinggi Ilmu Ekonomi AMA Salatiga" tidak dapat diterima atau ditolak.

\section{Pengujian Hipotesis II Penelitian}

Pengujian hipotesis II penelitian dilakukan dengan uji t. Pengujian hipotesis II penelitian ini bertujuan untuk mengetahui pengaruh kebutuhan afiliasi terhadap semangat kerja dosen pada Sekolah Tinggi Ilmu Ekonomi AMA Salatiga.

Dengan menggunakan taraf signifikansi 0,025 ( $\alpha=0,05 / 2)$, dan degree of freedom (n-k-1)

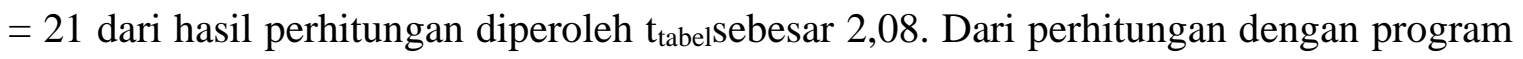

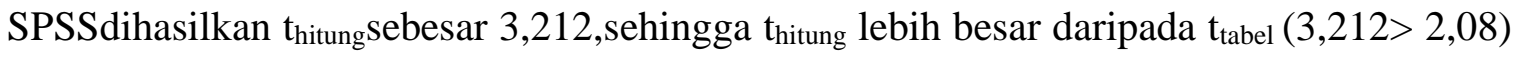
dengan tingkat signifikansi $0,004<0,025$, sehingga keputusannya adalah menolak $\mathrm{H}_{\mathrm{o}}$ dan menerima $\mathrm{H}_{\mathrm{a}}$.

Sehingga pernyataan hipotesis II penelitian "Terdapat pengaruh yang signifikan kebutuhan afiliasi terhadap semangat kerja dosen pada Sekolah Tinggi Ilmu Ekonomi AMA Salatiga" dapat diterima. 


\section{Pengujian Hipotesis III Penelitian}

Pengujian hipotesis III penelitian dilakukan dengan uji t. Pengujian hipotesis III penelitian ini bertujuan untuk mengetahui pengaruh kebutuhan kekuasaan terhadap semangat kerja dosen pada Sekolah Tinggi Ilmu Ekonomi AMA Salatiga.

Dengan menggunakan taraf signifikansi 0,025 ( $\alpha=0,05 / 2)$, dan degree of freedom $(\mathrm{n}-\mathrm{k}-1)$

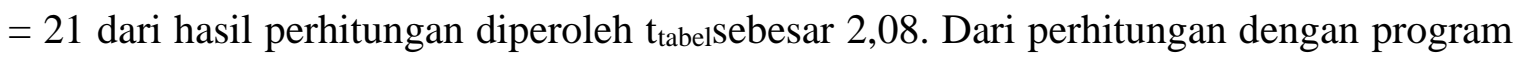

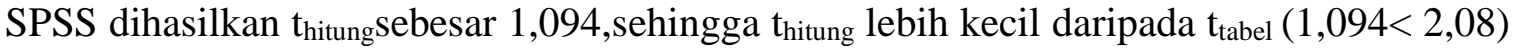
dengan tingkat signifikansi $0,004<0,025$, sehingga keputusannya adalah menerima $\mathrm{H}_{\mathrm{o}}$ dan menolak $\mathrm{H}_{\mathrm{a}}$.

Sehingga pernyataan hipotesis III penelitian "Terdapat pengaruh yang signifikan kebutuhan kekuasaan terhadap semangat kerja dosen pada Sekolah Tinggi Ilmu Ekonomi AMA Salatiga" tidak dapat diterima atau ditolak.

\section{Pengujian Hipotesis IV Penelitian}

Adapun pernyataan hipotesis IV penelitian adalah "Terdapat pengaruh yang signifikan kebutuhan prestasi, kebutuhan afiliasi dan kebutuhan kekuasaansecara simultan terhadap semangat kerja dosen pada Sekolah Tinggi Ilmu Ekonomi AMA Salatiga”.

Hasil uji $\mathrm{F}$ dengan menggunakan alat analisis regresi linier berganda dapat dilihat pada tabel di bawah ini :

Tabel 2

\section{Nilai F-hitung}

ANOVAb

\begin{tabular}{|l|r|r|r|r|r|}
\hline \multicolumn{1}{|l|}{ Model } & Sum of Squares & df & Mean Square & F & Sig. \\
\hline Regression & 34.043 & 3 & 11.348 & 4.770 & $.011^{\mathrm{a}}$ \\
Residual & 49.957 & 21 & 2.379 & & \\
Total & 84.000 & 24 & & & \\
\hline
\end{tabular}

a. Predictors: (Constant), KEBUTUHAN KEKUASAAN (X3), KEBUTUHAN AFILIASI (X2), KEBUTUHAN PRESTASI (X1)

b. Dependent Variable: SEMANGAT KERJA (Y)

Sumber : Data Primer Yang Diolah, 2017

Berdasarkan tabel tersebut di atas dapat diuraikan bahwa nilai F-hitung hasil analisis regresi adalah sebesar 4,770. Kemudian dengan menggunakan signifikansi 5\% ( $\alpha$ 
$=0.05)$ dan degree of freedom $3(\mathrm{k})$ dan $21(\mathrm{n}-\mathrm{k}-1)$, dihasilkan nilai $\mathrm{F}_{\text {tabel }}$ sebesar 3,07. Sehingga nilai $F_{\text {hitung }}$ lebih besar daripada $F_{\text {tabel }}(4,770>3,07)$. Dengan tingkat signifikansi0,011<0,05. Hal ini berarti bahwa secara simultan variasi variabel-variabel independen mempunyai pengaruh yang signifikan terhadap variasi variabel dependen. Dengan demikian Hipotesis IV penelitian yang menyatakan "Terdapat pengaruh yang signifikan kebutuhan prestasi, kebutuhan afiliasi dan kebutuhan kekuasaansecara simultan terhadap semangat kerja dosen pada Sekolah Tinggi Ilmu Ekonomi AMA Salatiga" dapat

\section{diterima.}

\section{Koefisien Determinasi(AdjustedR Square)}

Koefisien determinasi digunakan untuk melihat berapa persen (\%) dari variasi variabel dependen ( $\mathrm{Y}=$ semangat kerja) dapat diterangkan oleh variasi dari variabel independen yang terdiri dari kebutuhan prestasi $\left(\mathrm{X}_{1}\right)$,kebutuhan afiliasi $\left(\mathrm{X}_{2}\right)$ dan kebutuhan $\operatorname{kekuasaan}\left(\mathrm{X}_{3}\right)$.

Dari hasil analisis data dengan menggunakan program SPSSdiperoleh nilai koefisien determinasi (Adjusted R Square) sebagai berikut:

Tabel 3

Koefisien Determinasi (Adjusted R Square)

\begin{tabular}{|l|r|r|r|r|}
\hline \multicolumn{1}{|c|}{ Model Summary } \\
\hline Model & $\mathrm{R}$ & R Square & \multicolumn{1}{c|}{$\begin{array}{c}\text { Adjusted R } \\
\text { Square }\end{array}$} & $\begin{array}{c}\text { Std. Error of the } \\
\text { Estimate }\end{array}$ \\
\hline 1 & $.637^{\mathrm{a}}$ & .405 & .320 & 1.54236 \\
\hline
\end{tabular}

a. Predictors: (Constant), KEBUTUHAN KEKUASAAN (X3), KEBUTUHAN AFILIASI (X2), KEBUTUHAN PRESTASI (X1)

Sumber : Data Primer Yang Diolah, 2017

Dari tabel tersebut di atas dapat dilihat bahwa besarnya nilai koefisien determinasi (Adjusted R. Square) dari hasil perhitungan adalah sebesar 0,32 atau $32 \%$. Hal ini berarti variasi variabel kebutuhan prestasi,kebutuhan afiliasi dan kebutuhan kekuasaandapat menjelaskan variasi variabel semangat kerja dosen sebesar $32 \%$ dan sisanya $68 \%$ dijelaskan oleh variabel lain yang tidak diteliti. 


\section{SIMPULAN}

Berdasarkan hasil analisis data dan pembahasan dapat disimpulkan sebagai berikut :

1. Persamaan regresi linier berganda dalam penelitian ini adalah $\mathrm{Y}=5,270+0,157 \mathrm{X} 1$ $+0,514 \mathrm{X} 2+0,137 \mathrm{X} 3$.

2. Hipotesis I penelitian "Terdapat pengaruh yang signifikankebutuhan prestasi terhadap semangat kerja dosen pada Sekolah Tinggi Ilmu Ekonomi AMA Salatiga" tidak dapat diterima atau ditolakdibuktikan dengan nilai thitung lebih kecil daripada tabel $(0,830<2,08)$ dan tingkat signifikansinya $0,416>0,025$.

3. Hipotesis II penelitian yang menyatakan "Terdapat pengaruh yang signifikan kebutuhan afiliasi terhadap semangat kerja dosen pada Sekolah Tinggi Ilmu Ekonomi AMA Salatiga" dapat diterima dibuktikan dengan nilai thitung lebih besar daripada $t_{\text {tabel }}(3,212>2,08)$ dan tingkat signifikansinya $0,004<0,025$.

4. Hipotesis III penelitian "Terdapat pengaruh yang signifikan kebutuhan kekuasaanterhadap semangat kerja dosen pada Sekolah Tionggi Ilmu Ekonomi AMA Salatiga" tidak dapat diterima atau ditolakdibuktikan dengan nilai thitung lebih kecil daripada $t_{\text {tabel }}(1,094<2,08)$ dan tingkat signifikansinya $0,286>0,025$.

5. Hipotesis IV penelitian "Terdapat pengaruh yang signifikan kebutuhan prestasi, kebutuhan afiliasidankebutuhan kekuasaansecara simultan terhadap semangat kerja dosen pada Sekolah Tinggi Ilmu Ekonomi AMA Salatiga" dapat diterima dibuktikan dengan nilai $F_{\text {hitung }}$ lebih besar daripada $\mathrm{F}_{\text {tabel }}(4,770>3,07)$ dan tingkat sigifikansinya $0,011<0,05$.

6. Nilai koefisien determinasi (Adjusted $R$ Square) dari hasil perhitungan adalah sebesar 0,32 atau $32 \%$. Hal ini berarti variasi variabel kebutuhan prestasi, kebutuhan afiliasidankebutuhan kekuasaandapatmenjelaskan variasi variabel semangat kerja dosen sebesar $32 \%$ dan sisanya $68 \%$ dijelaskan oleh variabel lain yang tidak diteliti. 


\section{SARAN}

Berdasarkan hasil penelitian dapat dilihat bahwa kontribusi variabel kebutuhan afiliasimempunyai pengaruhyang signifikan terhadap peningkatan semangat kerja dosen daripada variabel kebutuhan prestasi, dankebutuhan kekuasaan. Hal ini menunjukkan bahwa semangat kerja dosen STIE AMA Salatiga lebih dipengaruhi oleh faktorkebutuhan afiliasi, untuk itu saran yang dapat diberikan oleh peneliti sehubungan dengan hasil penelitian tersebut adalah: ada baiknya apabila pihak STIE AMA Salatiga dan Yayasan berusaha meningkatkan kebutuhan afiliasi seperti meningkatkankeinginan hubungan persahabatan dalam bekerja, meningkatkan keinginan hubungan yang melibatkan adanya saling pengertian, meningkatkan keinginan keberadaannya disukai dan diterima oleh orang lain dalam bekerja, meningkatkan pekerjaan dalam suasana kooperatif serta terhindarnya adanya konflik dengan orang lain dalam bekerja tanpa melupakankebutuhan prestasidankebutuhan kekuasaan guna meningkatkan semangat kerja dosen Sekolah Tinggi Ilmu Ekonomi AMA Salatiga. 


\section{DAFTAR PUSTAKA}

Arikunto, Suharsimi. 2002. Prosedur Penelitian Suatu Pendekatan Praktek. Jakarta, Rineka Cipta.

As'ad, Moh, 2002.Psikologi Industri, Edisi Ke-empat. Yogyakarta, Liberty.

Ghozali, Imam, 2001. Analisis Multivariate Dengan Program SPSS. Badan Penerbit Universitas Diponegoro, Semarang.

Gitosudarmo, Indrio dan I Nyoman Sudita, 2000.Perilaku Organisasi. Yogyakarta, BPFE.

Hasan, M. Iqbal, 2006. Analisis Data Penelitian Dengan Statistik. Bumi Aksara, Jakarta. Hasibuan, Malayu S.P., 2003. Organisasi Dan Motivasi. Jakarta, PT. Bumi Aksara.

Mangkunegara, A.A. Anwar Prabu. 2004. Manajemen Sumber Daya Manusia.Bandung, Penerbit Rosdakarya.

Munandar, Ashar Sunyoto, 2004. Psikologi Industri dan Organisasi. Jakarta, UI-Press.

Nitisemito, Alex S. 2001. Manajemen Personalia (Manajemen Sumber Daya Manusia).Jakarta, Ghalia Indonesia.

Reksohadiprodjo, Sukanto dan T. Hani Handoko. 2000. Organisasi Perusahaan. Yogyakarta, BPFE.

Sugiyono. 2006. Metode Penelitian Bisnis. Bandung, CV. Alfa Beta.

Sukandarrumidi. 2006. Metodologi Penelitian. Yogyakarta Gajah Mada University Press. 